\title{
KEBIJAKAN PEMERINTAH TENTANG PENGELOLAAN SATUAN PENDIDIKAN KEAGAMAAN: Tantangan Terhadap Implementasi Manajemen Berbasis Sekolah
}

\author{
Oleh: Siti Nur Hidayati*
}

\begin{abstract}
The Government's policy on educational management in Indonesia, (UUSPN No. 20.2003), promotes school autonomy through School Based Management (SBM). The system of the government as stated on PP No. 55 (2007) has also organized an implementation process of religious based school. However, the religious educational institutions are still under discrimination. In fact, Islamic educational institutions face the problem of curriculum, human resources, management, and financial. Therefore, the introduction of SBM is meant to develop the professionality and accountability of Islamic education.
\end{abstract}

KEYWORDS: Kebijakan, satuan pendidikan keagamaan, manajemen berbasis sekolah

KEBIJAKAN pemerintah menyelenggarakan pembaruan sistem pemerintahan yang sentralistik menjadi desentralistik merupakan dampak dari tuntutan reformasi total. Dampak reformasi pendidikan adalah melahirkan Undang-undang RI Nomor 20 Tahun 2003 tentang Sistem Pendidikan Nasional, yang meliputi demokratisasi pendidikan, peningkatan mutu pendidikan, penghapusan diskriminasi, serta perbaikan manajemen sistem pendidikan. Selain itu, perkembangan ilmu pengetahuan dan teknologi yang begitu pesat juga menuntut adanya pembaruan sistem pendidikan, agar sesuai dengan tuntutan global. Untuk mencapai hal tersebut, diperlukan strategi dengan memberdayakan semua komponen masyarakat melalui peran serta dalam penyelenggaraan dan pengendalian mutu layanan pendidikan.

Masyarakat Islam sebagai komponen bangsa, telah lama berpartisipasi dalam mewujudkan harapan dari undang-undang tersebut. Hal ini bisa dibuktikan dari sejarah munculnya madrasah di Indonesia, yang lebih didorong oleh kebutuhan dan prakarsa masyarakat Islam sendiri. Madrasah merupakan institusi pendidikan yang tumbuh dan berkembang dari dan oleh masyarakat. Dengan demikian, secara substansial, madrasah telah otonom. Berangkat dari kenyataan ini, maka pada dasarnya madrasah telah menerapkan model manajemen berbasis sekolah dan masyarakat.

*Magister Pendidikan Islam dari Universitas Islam Negeri Alauddin Makassar ini adalah guru Pendidikan Agama Islam pada SMP Negeri 1 Sokaraja, Jawa Tengah. 
Sejak diterbitkannya Undang-undang RI Nomor 2 Tahun 1989 tentang Sistem Pendidikan Nasional, madrasah secara institusi telah diakui sebagai bagian dari sistem pendidikan nasional, tetapi perwujudan makna pengakuan itu belum sesuai dengan jiwa undang-undang tersebut. Hal ini masih dirasakan sampai sekarang, misalnya alokasi anggaran untuk pembinaan dan pengembangan mutu madrasah jumlahnya sangat sedikit. Kenyataan ini membuat masyarakat Islam kecewa yang sejak lama telah memberi kontribusi terhadap pendidikan di negeri ini.

Terkait dengan masalah di atas, sebenarnya UU Nomor 20 Tahun 2003 tentang Sistem Pendidikan Nasional membawa angin segar bagi pendidikan keagamaan, termasuk madrasah. Karena, sebagaimana ditegaskan dalam pasal 4 ayat (1), bahwa pendidikan diselenggarakan secara demokratis dan tidak diskriminatif. ${ }^{1}$

Di sisi lain, terjadi dilema dalam pengelolaan pendidikan keagamaan. Meskipun secara substansial masuk dalam bagian sistem pendidikan nasional, tetapi pengelolaannya tetap ditangani oleh Departemen Agama yang tidak didesentralisasikan. Hal tersebut bisa menimbulkan kekhawatiran bagi umat Islam, karena Pemerintah Daerah menganggap pendidikan keagamaan menjadi tanggung jawab pemerintah pusat, dalam hal ini adalah Departemen Agama. Jika demikian, bukankah pengalaman pahit yang begitu panjang dari sejak UU No. 4 Tahun 1950 tentang Dasar-Dasar Pendidikan dan Pengajaran di Sekolah sampai dengan UU No. 2 Tahun 1989 tentang Sistem Pendidikan Nasional akan tetap dirasakan oleh masyarakat Islam?

Memperhatikan realitas yang dihadapi satuan pendidikan keagamaan tersebut, tampaknya masih tetap terjadi diskriminasi dalam penyelenggaraan pendidikan antara pendidikan umum dengan pendidikan keagamaan. Di satu sisi otonomi daerah sudah diberlakukan-termasuk dalam bidang pendidikan dengan manajemen berbasis sekolah-tetapi di sisi lain satuan pendidikan keagamaan masih sentralistik dan tertinggal dalam banyak hal, sehingga terdapat kesenjangan antara kebijakan pemerintah dengan penyelenggaraan satuan pendidikan keagamaan. Tulisan ini akan mengkaji kebijakan pemerintah tentang pengelolaan satuan pendidikan keagamaan Islam dalam konteks manajemen berbasis sekolah.

\section{KEBIJAKAN PENGELOLAAN SATUAN PENDIDIKAN KEAGAMAAN ISLAM}

Merespons itikad baik pemerintah dalam usahanya untuk menghilangkan diskriminasi sebagaimana ditegaskan dalam UUSPN Nomor 20 Tahun 2003, merupakan tantangan bagi satuan pendidikan keagamaan 
Islam, agar citra yang selama ini melekat; sekolah nomor dua, sebagian besar tenaga kependidikannya mismatch, underqualified, dan citra buruk lainnya, berupaya memperbaiki citra dengan meningkatkan kualitas, terutama tenaga pendidik dan kependidikan, sarana dan prasarana, kurikulum, pengelolaan, dan pembiayaannya, minimal memenuhi standar nasional. Kelima komponen inilah menurut pasal 35 ayat 2 UUSPN No. 20 Tahun 2003 dijadikan acuan standar nasional pendidikan.

Mewujudkan hal tersebut merupakan tugas berat bagi satuan pendidikan keagamaan yang mendapatkan dana terlalu sedikit dari pemerintah. Bagaimana tidak? Satuan-satuan pendidikan yang ada di bawah Departemen Pendidikan Nasional saja mengalami kesulitan, karena adanya disparitas kemampuan daerah untuk membiayai pendidikan, apalagi dengan satuan pendidikan keagamaan, misalnya madrasah yang didanai sangat minim.

Dengan disparitas kemampuan masing-masing daerah, pemerintah pusat harus memiliki peta yang jelas dan mengupayakan subsidi yang bervariasi untuk daerah yang berbeda kemampuannya. Jika tidak, otonomi daerah akan memperparah disparitas mutu pelayanan pendidikan antar daerah. Meskipun Pemerintah Daerah kabupaten/kota bertanggung jawab mengelola pendidikan dasar dan menengah demi meratanya mutu pendidikan, pemerintah pusat harus tetap berupaya agar memberikan dana sekurang-kurangnya $20 \%$ dari APBN. ${ }^{2}$

Penegasan pemerintah yang dituangkan dalam undang-undang, merupakan tantangan bagi masyarakat Islam, agar dalam mengelola pendidikan memiliki landasan falsafah, visi, dan konsep yang matang serta dapat dipertanggungjawabkan, sehingga program yang dijalankan, bukan sekedar berjalan apa adanya saja.

Mengingat semua penyelenggaraan pendidikan harus mengacu pada Peraturan Pemerintah No. 19 Tahun 2005 tentang Standar Nasional Pendidikan, maka dalam menyelenggarakan pendidikan, dituntut memenuhi mutu minimal yang ada dalam Standar Nasional Pendidikan tersebut. Selain itu, diperlukan pula strategi-strategi dalam pelaksanaannya, sehingga penyelenggaraan pendidikan dapat terwujud secara efektif dengan melibatkan berbagai pihak secara aktif .

Untuk penyelenggaraan satuan pendidikan keagamaan, pemerintah telah menerbitkan Peraturan Pemerintah Nomor 55 Tahun 2007 tentang Pendidikan Agama dan Pendidikan Keagamaan. PP tersebut secara implisit mengatur cara penyelenggaraan pendidikan keagamaan Islam dan keagamaan lainnya. Dalam pasal 13 ayat 4 disebutkan ketentuan-ketentuan tentang penyelenggaraan satuan pendidikan keagamaan dengan memper- 
hatikan persyaratan-persyaratan mencakup: isi pendidikan/kurikulum, jumlah dan kualifikasi pendidik dan tenaga kependidikan, sarana dan prasarana, sumber pembiayaan, sistem evaluasi, serta manajemen dan proses pembelajaran. Kemudian pada pasal 18 (tentang kurikulum) dan pasal 19 (tentang ujian nasional pendidikan diniyah dasar dan menengah), pemerintah memberi kewenangan kepada Menteri Agama untuk membuat peraturan lebih lanjut dengan tetap berpedoman pada Standar Nasional Pendidikan. Demikian juga pada ayat 5 pasal 13 di atas, disebutkan bahwa untuk pengaturan selanjutnya akan diatur via Peraturan Menteri Agama dengan berpedoman pada ketentuan Standar Nasional Pendidikan. ${ }^{3}$

Namun, sampai tulisan ini dimuat, Menteri Agama Belum mengeluarkan Peraturan untuk menindaklanjuti PP No. 55 Tahun 2007. Hal ini mengindikasikan bahwa sesungguhnya Depag belum siap-untuk tidak mengatakan tidak mampu-menerima limpahan tanggung jawab dari Pemerintah, atau hal ini mengisyaratkan bahwa pihak Depag ragu-ragu untuk mengelola satuan pendidikan keagamaan dengan dana yang terlampau kecil bila dibandingkan dengan alokasi dana untuk satuan pendidikan umum? Padahal tawaran pemerintah melalui PP tersebut, memberi peluang kepada Departemen Agama untuk menentukan hal-hal yang menjadi kebutuhan dalam penyelenggaraan dan pengelolaan satuan pendidikan keagamaan.

Kebijakan pemerintah melalui PP No. 19 Tahun 2005 dan PP No. 55 Tahun 2007 jelas berimplikasi terhadap perubahan pada sisi manajerial satuan pendidikan keagamaan, tidak terkecuali satuan pendidikan keagamaan Islam, sehingga perlu bagi Depag untuk membuat kebijakan yang diawali dengan melakukan analisis SWOT-nya terlebih dahulu. Apa yang diperlukan dan menjadi prioritas untuk menindaklanjuti PP tersebut. Hal ini perlu, mengingat ketertinggalan yang dialami satuan pendidikan keagamaan Islam selama ini.

\section{PROBLEMATIKA SATUAN PENDIDIKAN KEAGAMAAN ISLAM}

Jika dilihat dari aspek perluasan dan pemerataan akses, keberhasilan penyelenggaraan satuan pendidikan keagamaan Islam tercermin misalnya dari tingginya angka partisipasi masyarakat Islam, terutama pada Program Wajib Belajar Pendidikan Dasar. Keberhasilan ini terkait erat dengan komitmen keberpihakan satuan pendidikan keagamaan Islam terhadap kaum miskin di tengah belum pulihnya kondisi perekonomian nasional. Namun, jika dilihat dari aspek mutu dan daya saing, pada umumnya satuan pendidikan-satuan pendidikan keagamaan Islam masih berada di bawah standar nasional, terutama dalam hal pengelolaannya. Performa 
satuan pendidikan keagamaan Islam masih dibayang-bayangi oleh citra pendidikan yang tertinggal. Kondisi ini menunjukkan belum optimalnya upaya peningkatan mutu satuan pendidikan keagamaan Islam.

Demikian pula kondisi gedung dan sarana pendidikan, masih jauh dari standar minimal pelayanan. Hal ini disebabkan sebagian besar gedung dan sarana yang ada merupakan hasil swadana dari masyarakat, kalaupun ada subsidi dari pemerintah, jumlahnya sangat sedikit. Sebagai contoh, anggaran Dirjen Pendidikan Islam tahun 2007 adalah senilai Rp 7 triliun. Anggaran ini diperuntukkan bagi banyak komponen pendidikan, seperti gaji guru dan tenaga kependidikan (57,1 \%), dana BOS BKM dan BOS buku $(25,7 \%)$, sisanya sebagai anggaran tugas pokok dan fungsi (tupoksi) empat direktorat Depag dan bidang Mapenda serta Pondok pesantren (Pontren) di 32 Kanwil Depag Provinsi (17,1 \%) atau sekitar Rp 1,2 triliun. Untuk saat ini, anggaran pendidikan keagamaan Islam di Depag diprediksi 20\% dari anggaran pendidikan di Depdiknas (bukan dari APBD). ${ }^{4}$

Persoalan lain yang dihadapi satuan pendidikan keagamaan Islam adalah belum mampu menerapkan Manajemen Peningkatan Mutu Berbasis Madrasah (MPMBM). Persoalan berikutnya, pada pemenuhan Standar Penilaian Pendidikan, yaitu masih rendahnya pemahaman kepala madrasah dan pendidik terhadap standar penilaian. Sebagai contoh, soal penetapan Kriteria Ketuntasan Minimal (KKM) pada masing-masing mata pelajaran, sebagai akibat dari perbedaan penafsiran pada panduan KKM. Belum lagi rendahnya pemahaman tentang alat evaluasi yang lainnya. ${ }^{5}$

Permasalahan yang dihadapi satuan pendidikan keagamaan Islam di atas, masih ditambah lagi dengan jumlah satuan pendidikan keagamaan swasta (sebagian besar madrasah di Indonesia adalah swasta) ${ }^{6}$, yang kurang mendapat perhatian dari pemerintah. Kondisi ini semakin terpuruk karena sebagian lokasi madrasah berada di daerah pinggiran dan pedesaan, sehingga akses informasi pun sangat sulit. Padahal, jika ditinjau dari sejarah perkembangan madrasah, hampir semua madrasah di lingkungan Departemen Agama berasal dari madrasah swasta yang dinegerikan. Hampir tidak ditemukan madrasah negeri yang didirikan secara khusus. ${ }^{7}$ Kondisi demikian jelas menambah kesulitan dalam pengelolaan, terkait dengan faktor pendanaan.

Persoalan di atas belum termasuk masalah pengembangan kurikulum. Kebijakan pendidikan nasional yang selama ini sentralistik telah berdampak terhadap masyarakat yang serba tergantung pada budaya menunggu petunjuk dan kebijakan dari instansi yang ada di atasnya, sehingga setiap keputusan yang akan dijalankan pun tentu akan seragam (budaya uniformitas). Dalam masalah pengembangan kurikulum, budaya 
semacam itu sangat kental mewarnai satuan pendidikan keagamaan Islam. Lihat saja ketika diadakan workshop tentang pembuatan silabus maupun perangkat pembelajaran yang lain, sebagian besar peserta hanya mengekor pada peserta yang terlihat mampu. Sehingga hasilnya pun didapati perangkat pembelajaran yang seragam. Setelah tiba di tempat tugas, mereka hanya mengganti identitas satuan pendidikannya saja. Padahal kondisi masing-masing satuan pendidikan belum tentu sama, sehingga kebutuhan silabus dan perangkat pembelajarannya pun belum tentu sama.

Hal yang demikian, mengindikasikan bahwa sumber daya manusia yang dimiliki satuan pendidikan keagamaan Islam masih sangat memprihatinkan (underqualified). Indikasi tersebut diperkuat dengan data yang ditemukan oleh Madrasah Development Center (MDC). ${ }^{8}$

Problematika yang dihadapi satuan pendidikan keagamaan Islam sebagaimana penulis kemukakan di atas, menunjukkan bahwa meskipun MBS bukan hal baru bagi institusi ini, namun karena kebijakan pemerintah dalam pengelolaan yang masih terkesan diskriminatif, maka satuan pendidikan keagamaan Islam tetap saja mengalami banyak ketertinggalan.

\section{IMPLEMENTASI MANAJEMEN BERBASIS SEKOLAH PADA SATUAN PENDIDIKAN KEAGAMAAN ISLAM}

Departemen Agama sebagai penanggung jawab dalam pengelolaan satuan pendidikan keagamaan, sudah seharusnya mengembangkan suatu sistem perbaikan yang berkesinambungan, dan peningkatan mutu yang berkelanjutan (continuous quality improvement). Perbaikan-perbaikan yang selama ini dilakukan Depag, lebih bersifat parsial dan terkesan bersifat tambal sulam saja.

Semestinya, dengan diberlakukannya UUSPN No. 20 Tahun 2003, Depag tidak lagi mengalami ketertinggalan dengan Depdiknas dalam hal perbaikan dan peningkatan mutu. Ini merupakan tuntutan yang harus direspons atas diberlakukannya status yang sama antara pendidikan umum dan pendidikan keagamaan. Status yang non-diskriminatif tersebut merupakan tantangan bagi Depag sebagai pengelola satuan pendidikan keagamaan Islam agar senantiasa mengurangi ketertinggalan dalam banyak hal.

Untuk mewujudkan itu semua, implementasi manajemen berbasis sekolah menjadi urgen. Hal ini diperkuat oleh pasal 51 ayat (1) UUSPN Nomor 20 Tahun 2003 dan pasal 49 ayat (1) PP No. 19 Tahun 2005 tentang Standar Nasional Pendidikan. ${ }^{9}$ Kedua pasal tersebut menyatakan bahwa dalam pengelolaan satuan pendidikan dasar dan menengah dengan menerapkan prinsip manajemen berbasis sekolah, yang ditunjukkan 
dengan kemandirian, kemitraan, partisipasi, keterbukaan, dan akuntabilitas. Dengan penerapan MBS, diharapkan akan meningkatkan keprofesionalan dan akuntabilitas satuan pendidikan (keagamaan Islam) sebagai pusat pembudayaan ilmu pengetahuan, keterampilan, pengalaman, sikap, dan nilai berdasarkan standar nasional dan global.

Sesuai dengan pasal 35 ayat 2 UUSPN No. 20 Tahun 2003, bahwa "Standar nasional pendidikan digunakan sebagai acuan pengembangan kurikulum, tenaga kependidikan, sarana dan prasarana, pengelolaan, dan pembiayaan"10, maka dalam implementasi MBS, komponen-komponen inilah yang harus dimanaj, sehingga output-nya lebih profesional dan akuntabel.

Menurut Zainuddin, pengembangan konsep manajemen ini didesain untuk meningkatkan kemampuan satuan pendidikan dan masyarakat dalam mengelola perubahan pendidikan. Pendekatan ini menuntut adanya perubahan sikap dan tingkah laku seluruh komponen satuan pendidikan dalam memahami, membantu, dan memantau pengelolaannya dengan didukung oleh pengelolaan sistem informasi yang valid. ${ }^{11}$ Kehadiran pola manajemen berbasis sekolah membawa konsekuensi adanya sorotan terhadap kinerja satuan pendidikan, khususnya dari sudut pandang input, proses, output, dan dampaknya. ${ }^{12}$

Kemudian untuk mengimplementasikan MBS pada satuan pendidikan keagamaan Islam, paling tidak didukung oleh lima aspek, yaitu: iklim madrasah yang kondusif, otonomi madrasah, kewajiban madrasah, kepemimpinan madrasah yang demokratis dan profesional, dan revitalisasi partisipasi masyarakat. ${ }^{13}$

Berkaitan dengan poin pertama di atas, Mulyasa berpendapat, jika suatu lembaga pendidikan didukung oleh sarana dan prasarana serta sumber belajar yang kondusif, maka proses pembelajaran pun berlangsung nyaman dan menyenangkan (enjoyble learning), sehingga mendorong proses pembelajaran yang efektif, yang lebih menekankan pada belajar mengetahui (learning to know), belajar berkarya (learning to do), belajar menjadi diri sendiri (learning to be), dan belajar hidup bersama secara harmonis (learning to live together). ${ }^{14}$ Rasionalnya, jika suasana suatu lembaga pendidikan kondusif, terlebih dapat memanfaatkan semua potensi yang dimiliki secara maksimal, maka akan terjadi proses pembelajaran yang optimal pula, sehingga fungsi suatu lembaga sebagai pusat pembudayaan ilmu pengetahuan, keterampilan, sikap, dan nilai akan terwujud.

Sistem sentralisasi yang telah lama mengakar pada setiap bidang pemerintahan, tidak mudah untuk dirubah ke paradigma desentralisasi. Bagi satuan pendidikan keagamaan Islam, ini bukan hal yang mudah, 
karena sekian lama dikondisikan dengan budaya menunggu ketentuan dari pusat, dan cenderung hanya sebagai pelaksana ketentuan pusat saja.

Pemerintah dengan kesungguhannya dalam merespons reformasi dalam bidang pendidikan, yaitu dengan diundangkannya UUSPN No. 20 Tahun 2003-dengan penerapan MBS-nya-menghendaki adanya kemandirian satuan pendidikan-satuan pendidikan. Hal inilah yang menurut Mulyasa, bahwa dalam MBS, kebijakan pengembangan kurikulum dan pembelajaran beserta sistem evaluasinya harus didesentralisasikan ke madrasah, agar sesuai dengan kebutuhan peserta didik dan masyarakat secara lebih fleksibel. ${ }^{15}$ Kemudian untuk muatan kurikulum, Azyumardi mengingatkan agar tidak keluar dari filsafat yang mendasari kurikulum satuan pendidikan. Lebih lanjut diungkapkan bahwa muatan kurikulum setidaknya memenuhi syarat kebisaan untuk dipelajari (learnability), serta konsistensi dan relevansi dengan realitas sosial. ${ }^{16}$ Selain itu, Westmeyer menekankan bahwa dalam pengembangan kurikulum mesti mempertimbangkan permintaan client. ${ }^{17}$ Client utama sekolah - penulis mengistilahkan dengan pelanggan primer dalam dunia pendidikan - adalah peserta didik. Selain itu, aspek budaya juga perlu dipertimbangkan.

Menyikapi pendapat di atas, memang semestinya pihak Diknas dan Depag (Pemerintahan Pusat) tidak lagi melakukan intervensi terhadap kurikulum dan evaluasinya (termasuk UNAS; tidak perlu diadakan lagi). Satuan pendidikan yang menyelenggarakan, mereka pula yang lebih mengerti bagaimana prosesnya, sehingga yang lebih berkepentingan dalam evaluasinya pun satuan pendidikan dan masyarakat sebagai pemiliknya. Inilah sesungguhnya yang dinamakan otonomi lembaga yang menjadi prasyarat dalam implementasi MBS.

Untuk mewujudkan otonomi lembaga diperlukan kesiapan sumber daya manusianya yang mampu merumuskan, mengembangkan, dan mengadakan evaluasi secara otonom. Paling tidak, ini diawali perbaikan kepemimpinannya terlebih dahulu. Hasil studi Burns tentang kepemimpinan, menunjukkan bahwa pemimpin yang paling sukses untuk melakukan perubahan adalah yang berusaha menerapkan kepemimpinan transformatif atau transformasional. ${ }^{18}$ Kepemimpinan transformatif sangat diperlukan dalam satuan pendidikan keagamaan Islam. Sebagian besar $(90 \%)^{19}$ madrasah adalah swasta, sebagian berlindung di bawah yayasan, yang kental dengan nuansa kepemimpinan yang paternalistik. Dengan kondisi yang demikian, tentu harus ada political will dari para pimpinan di satuan pendidikan keagamaan Islam, untuk merubah pola kepemimpinan menjadi lebih transformatif. 
Dalam implementasinya, MBS dan peran serta masyarakat ibarat dua sisi mata uang. Keduanya harus berjalan sinergis. Dengan partisipasi/ pelibatan warga sekolah, rasa memiliki terhadap sekolah dapat ditingkatkan. Peningkatan rasa memiliki ini akan mendorong peningkatan rasa tanggung jawab dan akan berimplikasi pada dedikasi warga sekolah dan masyarakat terhadap sekolah.

Peran serta masyarakat telah diatur dalam suatu kelembagaan yang disebut dengan Komite Sekolah. Secara resmi keberadaan Komite Sekolah ditunjukkan melalui Surat Keputusan Mendiknas Nomor 044/U/2002 tentang Dewan Pendidikan dan Komite Sekolah. ${ }^{20}$ Dalam hal ini, Komite Sekolah dituntut bukan hanya dalam masalah pendanaan atau berperan sebagai pengetok palu pada saat sosialisasi program saja, melainkan secara bersama-sama merumuskan peningkatan kualitas sampai pada persoalan akuntabilitas lembaga.

Peran serta masyarakat harus dibarengi pula dengan prinsip kemitraan, termasuk dunia kerja dan dunia industri yang nantinya menjadi pemakai output lembaga tersebut. Dalam hal ini, para pimpinan satuan pendidikan keagamaan Islam semestinya memiliki jaringan luas dengan dinas pemerintahan, perusahaan, dan dunia kerja lainnya. Salah satu jalan yang ditempuh misalnya dengan menjalin hubungan dengan alumni yang sukses.

Berkaitan dengan pasal 13 ayat (4) PP No. 55 Tahun 2007, bahwa syarat penyelenggaraan satuan pendidikan keagamaan harus memperhatikan hal-hal sebagai berikut: a) isi pendidikan/kurikulum; b) jumlah dan kualifikasi pendidik dan tenaga kependidikan; c) sarana dan prasarana yang memungkinkan terselenggaranya kegiatan pembelajaran; d) sumber; pembiayaan untuk kelangsungan program pendidikan; e) sistem evaluasi; dan f) manajemen dan proses pendidikan, ${ }^{21}$ maka lagi-lagi satuan pendidikan dihadapkan dengan berbagai hal yang menuntut kesiapan sumber daya (resources) dalam implementasi MBS, dalam arti keenam syarat tersebut dikelola secara profesional, memenuhi tuntutan masyarakat sebagai user dan dapat dipertanggungjawabkan (akuntabel). Untuk mewujudkannya, diperlukan paling tidak tiga kompetensi, yaitu: kompetensi teknis, kompetensi shareholder (user), dan kompetensi manajemen. ${ }^{22}$ Ketiga kompetensi ini perlu dikuasai dengan baik oleh satuan pendidikan keagamaan Islam.

Berkaitan dengan upaya untuk meningkatkan kualitas, Depag telah menjalin kerjasama dengan ADB Loan berupa BEP (Basic Education Project) untuk MI dan MTs, dan DMAP (Development Madrasah Aliyah Project). ${ }^{23}$ Kerja sama ini sangat direspons positif, meskipun baru diprioritaskan 
untuk madrasah negeri. Namun demikian, hasil kerjasama tersebut cukup menggembirakan. Bahkan menurut Muhaimin, hasil tersebut memenuhi tiga tuntutan minimal dalam peningkatan kualitas madrasah, yaitu: perta$m a$, bagaimana menjadikan madrasah sebagai wahana pembinaan ruh atau praktik hidup keislaman, kedua, bagaimana madrasah tidak ter-marginalkan oleh sekolah umum, ketiga, bagaimana madrasah mampu merespons tuntutan masa depan guna mengantisipasi perkembangan iptek dan era globalisasi. ${ }^{24}$

Pelatihan-pelatihan yang diselenggarakan oleh Depag, berupa pelatihan manajemen, peningkatan kualitas tenaga pendidik dan kependidikan, pengembangan kurikulum, mestinya dilakukan secara rutin dan terus dikembangkan. Pendekatan dengan Total Quality Management (TQM) dan Manajemen Mutu Sumber Daya Manusia (MMSDM) sudah saatnya digunakan dalam peningkatan kualitas satuan pendidikan keagamaan Islam. Upaya tersebut dapat dilakukan melalui kerja sama dengan Dinas Pendidikan dan Pemerintah Daerah dalam pengadaan nara sumbernya, sehingga sampai pada pengembangan quality education vis-à-vis sistem pendidikan umum. Dengan mempertimbangkan faktor-faktor tersebut, satuan pendidikan keagamaan Islam optimis bisa bersaing dan mampu menghadapi tantangan baik nasional maupun global, tanpa harus kehilangan ciri khasnya ${ }^{25}$, sebagaimana dikhawatirkan sebagian kalangan.

Mengenai bidang sarana dan prasarana yang belum memadai, pendekatan efisiensi bisa dijadikan alternatif. Pendekatan ini digunakan untuk mengantisipasi keterbatasan dalam anggaran. Prinsip ini dikenal sebagai prinsip dasar dalam manajemen ketika terjadi keterbatasan dalam sumber daya. Efisiensi menurut Drucker adalah the extent to wich the result produced was produced at least cost. ${ }^{26}$

Prinsip tersebut juga sejajar dengan prinsip yang dinyatakan dalam UUSPN No. 20 Tahun 2003 pasal 48 ayat (1), bahwa "pengelolaan dana pendidikan dengan prinsip keadilan, efisiensi, transparansi, dan akuntabilitas". Fenomena yang terjadi di masyarakat sekarang ini, hampir di setiap desa didirikan satuan pendidikan keagamaan Islam, terutama MTs. Dengan pendekatan efisiensi, mestinya tidak perlu dilakukan. Akan lebih efektif apabila MTs-MTs yang berjarak tidak terlalu jauh digabung-kan saja, sehingga dana yang digunakan untuk operasional pendirian MTs, bisa dimanfaatkan untuk peningkatan kualitas. Secara keilmuan, penggabungan ini didukung oleh pemikiran Herbert Simon yang mengemukakan bahwa alasan penyelenggaraan desentralisasi mengacu kepada dua alasan dan tujuan, yaitu efficiency and adequacy. ${ }^{27}$ Artinya, untuk pencapaian kinerja, tidak selalu diselesaikan dengan pemekaran atau pembentukan lembaga, karena konsekuensi logisnya adalah peningkatan biaya kelembagaan. 
Namun, rasa optimisme harus dikedepankan, sehingga implementasi MBS dalam penyelenggaraan satuan pendidikan keagamaan (Islam) dapat diwujudkan dengan optimal. Komitmen dan kerja keras dari stakeholders pada satuan pendidikan keagamaan Islam sangat diperlukan, sehingga satuan pendidikan keagamaan Islam menjadi suatu lembaga bukan saja diakui keberadaannya, tetapi merupakan satuan pendidikan yang benarbenar profesional dan akuntabel.

Dengan demikian, tidak ada lagi kekhawatiran bahwa implementasi MBS akan mandul oleh karena keterbatasan sumber daya (resources) dan kurikulum yang tidak terarah. Akan tetapi yang lebih penting adalah bagaimana upaya meningkatkan kualitas pada satuan pendidikan keagamaan Islam, tanpa banyak bergantung kepada pemerintah-dengan dana yang sangat kecil-melainkan dengan kemandirian dari stakeholders pada satuan pendidikan keagamaan Islam.

\section{PENUTUP}

Kebijakan pemerintah melalui Undang-undang Nomor 20 Tahun 2003 tentang Sistem Pendidikan Nasional, bertekad menghilangkan diskriminasi. Berdasarkan UU ini pula, Manajemen Berbasis Sekolah (MBS) menjadi prinsip dalam penyelenggaran satuan pendidikan dasar dan menengah, dan harus memenuhi mutu minimal yang ada dalam Standar Nasional Pendidikan. Sedangkan untuk penyelenggaraan satuan pendidikan keagamaan, pemerintah mengaturnya melalui PP No. 55 Tahun 2007. Tuntutan UU dalam hal pengelolaan satuan pendidikan, merupakan beban berat bagi satuan pendidikan keagamaan Islam yang memiliki sumber daya sangat terbatas, dan pengelolaannya diserahkan kepada Departemen Agama yang masih sentralistik. Padahal untuk pendidikan umum, pengelolaannya dilimpahkan ke Pemerintah Daerah. Di sini masih tampak ada diskriminasi dalam pengeloaannya.

Problematika yang dihadapi satuan pendidikan keagamaan Islam antara lain: pertama, pembiayaan dalam penyelenggaraan pendidikan sangat minim; kedua, tenaga pendidik dan kependidikan belum memenuhi standar kompetensi; ketiga, sarana dan prasarana yang masih meprihatinkan, karena sebagian besar merupakan hasil swadana masyarakat; keempat, tidak optimal dalam pengembangan kurikulum, karena terkungkung kebijakan yang sentralistik.

Tercapainya profesionalitas dan akuntabilitas yang optimal merupakan tantangan dalam implementasi MBS pada satuan pendidikan keagamaan Islam, karena hampir sepanjang berdirinya negara Indonesia, institusi ini kurang pembinaan dari pemerintah. 


\section{CATATAN AKHIR:}

1. Lihat Republik Indonesia, Undang-undang Nomor 20 Tahun 2003, cet. I; Bandung: Citra Umbara, 2008, h. 6.

2. Soedijarto, Landasan dan Arah Pendidikan Nasional Kita, Jakarta: Penerbit Buku Kompas, 2008, h. 293.

3. Republik Indonesia, Peraturan Pemerintah Nomor 55 Tahun 2007, t.d.

4. Muhammad Idrus, "Evaluasi Kebijakan Pemerintah dalam Bidang Pendidikan Islam," MSI-UII.Net, 16/9/2008, diakses 10 Januari 2009 [muhammadidrus @fiai.uii.ac.id].

5. Khaeruddin, et al., Kurikulum Tingkat Satuan Pendidikan: Konsep dan Implementasinya di Madrasah, cet. II; Yogyakarta: Pilar Media bekerja sama dengan Madrasah Development Center (MDC), 2007, h. 12-13.

6. Untuk madrasah di Jawa Tengah yang berjumlah 5.555 buah, $94,69 \%$ adalah madrasah swasta, dan 5,30 \% madrasah negeri. Lihat Khaeruddin, et al., Kurikulum Tingkat Satuan Pendidikan: Konsep dan Implementasinya di Madrasah, $\mathrm{h}$. ix. Di Sulawesi Selatan, jumlah madrasah dari tingkat Ibtidaiyah, Tsanawiyah, dan Aliyah, semuanya berjumlah 1.319 buah, dan 1.209 madrasah swasta, 110 madrasah negeri. Lihat Abd. Rahman Halim, "Kebijakan dan Partisipasi Masyarakat: Studi Kritis Terhadap Perspektif Pembinaan Madrasah Swasta di Sulawesi Selatan", Disertasi; Yogyakarta: Universitas Islam Negeri Sunan Kalijaga, 2007, h. 3. Kondisi ini hampir terjadi di seluruh wilayah di Indonesia.

7. Husni Rahim, Madrasah dalam Politik Pendidikan di Indonesia, Jakarta: Logos Wacana Ilmu, t.t, h. 159.

8. Lihat Khaeruddin, et al., Kurikulum Tingkat Satuan Pendidikan: Konsep dan Implementasinya di Madrasah, h. 12-13.

9. Lihat Republik Indonesia, Undang-undang Nomor 20 Tahun 2003, h. 27. Lihat pula Republik Indonesia, Peraturan Pemerintah Nomor 19 Tahun 2005 tentang Standar Nasional Pendidikan, cet. III; Jakarta: Sinar Grafika, 2007, h. 28.

10. Lihat Republik Indonesia, Peraturan Pemerintah Nomor 19 Tahun 2005 tentang Standar Nasional Pendidikan, h. 19.

11. Lihat Zainuddin, Reformasi Pendidikan: Kritik Kurikulum dan Manajemen Berbasis Sekolah, cet. I; Yogyakarta: Pustaka Pelajar, 2008, h. 71. Baca juga H.A.R. Tilaar, Membenahi Pendidikan Nasional, cet. I; Jakarta: Rineka Cipta, 2002, h. 76-77. Bandingkan dengan Hasbullah, Otonomi Pendidikan: Kebijakan Otonomi Daerah dan Implikasinya terhadap Penyelenggaraan Pendidikan, Jakarta: RajaGrafindo Persada, 2007, h. 3.

12. Sudarwan Danim, Visi Baru Manajemen Sekolah: Dari Unit Birokrasi ke Lembaga Akademik, cet. I; Jakarta: Bumi Aksara, 2006, h. vii.

13. E. Mulyasa, Pedoman Manajemen Berbasis Madrasah, Departemen Agama RI: Direktorat Kelembagaan Agama Islam dan Direktorat Madrasah dan Pendidikan Agama Islam, 2003, h. 22-26.

14. E. Mulyasa, Pedoman Manajemen Berbasis Madrasah, h. 22-26.

15. E. Mulyasa, Pedoman Manajemen Berbasis Madrasah, h. 23.

16. Azyumardi Azra, Paradigma Baru Pendidikan Nasional: Rekonstruksi dan Demokratisasi, cet. I; Jakarta: Penerbit Buku Kompas, 2002, h. 99.

17. Dede Rosyada, Paradigma Pendidikan Demokratis: Sebuah Model Pelibatan Masyarakat dalam Penyelenggaraan Pendidikan, cet. III; Jakarta: Kencana, 2007, h. 
86. Lihat pula M. Sirozi, Politik Pendidikan: Dinamika Hubungan antara Kepentingan Kekuasaan dan Praktik Penyelenggaraan Pendidikan, Jakarta: RajaGrafindo Persada, 2007, h. 207.

18. Sulthon Masyhud, et al., Manajemen Pondok Pesantren, Jakarta: Diva Pustaka, 2004, h. 41.

19. Data Statistik di Jawa Timur tahun 2003. Lihat Muhaimin, Pengembangan Kurikulum Pendidikan Agama Islam: di Sekolah, Madrasah, dan Perguruan Tinggi, Jakarta: RajaGrafindo Persada, 2007, h. 185.

20. Rohiat, Manajemen Sekolah: Teori dan Praktik, cet. I; Bandung: Refika Aditama, 2008, h. 48.

21. Lihat Republik Indonesia, Peraturan Pemerintah Nomor 55 Tahun 2007.

22. H.A.R. Tilaar, Membenahi Pendidikan Nasional, h. 83.

23. Muhaimin, Pengembangan Kurikulum Pendidikan Agama Islam: di Sekolah, Madrasah, dan Perguruan Tinggi, h. 188.

24. Muhaimin, Pengembangan Kurikulum Pendidikan Agama Islam: di Sekolah, Madrasah, dan Perguruan Tinggi, h. 188.

25. Muhaimin, Pengembangan Kurikulum Pendidikan Agama Islam: di Sekolah, Madrasah, dan Perguruan Tinggi, h. 188.

26. Riant Nugroho, Kebijakan Pendidikan Unggul, Yogyakarta: Pustaka Pelajar, 2008, h. 119.

27. Riant Nugroho, Kebijakan Pendidikan Unggul, h. 117.

\section{DAFTAR PUSTAKA:}

Azra, Azyumardi, Paradigma Baru Pendidikan Nasional: Rekonstruksi dan Demokratisasi, cet. I; Jakarta: Penerbit Buku Kompas, 2002.

Danim, Sudarwan, Visi Baru Manajemen Sekolah: Dari Unit Birokrasi ke Lembaga Akademik, cet. I; Jakarta: Bumi Aksara, 2006.

Halim, Abd. Rahman, "Kebijakan dan Partisipasi Masyarakat: Studi Kritis Terhadap Perspektif Pembinaan Madrasah Swasta di Sulawesi Selatan", Disertasi; Yogyakarta: Universitas Islam Negeri Sunan Kalijaga, 2007.

Hasbullah, Otonomi Pendidikan: Kebijakan Otonomi Daerah dan Implikasinya terhadap Penyelenggaraan Pendidikan, Jakarta: RajaGrafindo Persada, 2007.

Idrus, Muhammad, "Evaluasi Kebijakan Pemerintah dalam Bidang Pendidikan Islam", MSI-UII.Net, 16/9/2008, diakses 10 Januari 2009 [muhammadidrus @fiai.uii.ac.id].

Imran, Ali, Kebijaksanaan Pendidikan di Indonesia: Proses, Produk \& Masa Depannya, cet. III; Jakarta: Bumi Aksara, 2008.

Khaeruddin, et al., Kurikulum Tingkat Satuan Pendidikan: Konsep dan Implementasinya di Madrasah, cet. II; Yogyakarta: Pilar Media bekerja sama dengan Madrasah Development Center (MDC), 2007.

Masyhud, Sulthon, et al., Manajemen Pondok Pesantren, Jakarta: Diva Pustaka, 2004.

Muhaimin, Pengembangan Kurikulum Pendidikan Agama Islam: di Sekolah, Madrasah, dan Perguruan Tinggi, Jakarta: RajaGrafindo Persada, 2007.

Mulyasa, E., Pedoman Manajemen Berbasis Madrasah, Departemen Agama RI: Direktorat Kelembagaan Agama Islam dan Direktorat Madrasah dan Pendidikan Agama Islam, 2003. 
Nugroho, Riant, Kebijakan Pendidikan Unggul, Yogyakarta: Pustaka Pelajar, 2008.

Rahim, Husni, Madrasah dalam Politik Pendidikan di Indonesia, Jakarta: Logos Wacana Ilmu, t.th.

Republik Indonesia, Undang-undang Dasar 1945, t.d.

------, Undang-undang Nomor 20 Tahun 2003 tentang Sistem Pendidikan Nasional, cet. I; Bandung: Citra Umbara, 2008.

------, Peraturan Pemerintah Nomor 19 Tahun 2005 tentang Standar Nasional Pendidikan, cet. III; Jakarta: Sinar Grafika, 2007.

------, Peraturan Pemerintah Nomor 55 Tahun 2007, t.d.

Rohiat, Manajemen Sekolah: Teori dan Praktik, cet. I; Bandung: Refika Aditama, 2008.

Rosyada, Dede, Paradigma Pendidikan Demokratis: Sebuah Model Pelibatan Masyarakat dalam Penyelenggaraan Pendidikan, cet. III; Jakarta: Kencana, 2007.

Sirozi, M., Politik Pendidikan: Dinamika Hubungan antara Kepentingan Kekuasaan dan Praktik Penyelenggaraan Pendidikan, Jakarta: RajaGrafindo Persada, 2007.

Soedijarto, Landasan dan Arah Pendidikan Nasional Kita, Jakarta: Penerbit Buku Kompas, 2008.

Tilaar, H.A.R., Membenahi Pendidikan Nasional, cet. I; Jakarta: Rineka Cipta, 2002.

Zainuddin, Reformasi Pendidikan: Kritik Kurikulum dan Manajemen Berbasis Sekolah, cet. I; Yogyakarta: Pustaka Pelajar, 2008. 